\title{
The Metabolic Significance of the Citric Acid Cycle in the Growth of the Fungus Zygorrhynchus moelleri
}

\author{
By V. MOSES* \\ Botany Department, University College, London
}

SUMMARY : Cultures of the fungus Zygorrhynchus moelleri were grown in a glucoseacetate + ammonia + salts medium in the presence of either radioactive carbon dioxide, or acetate labelled in either the methyl- or the carboxyl-positions. After growth the protein was hydrolysed and the pattern of incorporation of radiocarbon into the amino acids was determined by chromatography and radioautography; activity from carbon dioxide appeared in glutamic and aspartic acids, methionine, threonine, isoleucine, proline and arginine. With labelled acetate lysine and leucine were also radioactive. A pool of free amino acids was present in this fungus.

Several amino acids were isolated from the three samples of hydrolysed proteir. and their specific activities were determined. Assuming that the tricarboxylic acid cycle operated in this organism, a number of predictions concerning the distribution of radiocarbon in certain amino acids which could be made were largely confirmed by the experimental findings. By partial degradation of glutamic and aspartic acids, followed by assay of the radioactivity in the products, it was possible to calculate that about $60 \%$ of the oxalacetate used for citrate synthesis was recycled $\mathrm{C}_{4}$-dicarboxylic acid; $40 \%$ was synthesized from pyruvate and carbon dioxide. Approximately $25 \%$ of the total respiratory carbon dioxide evolved could be accounted for in terms of decarboxylations occurring within the citric acid cycle.

A great deal of effort in recent years has been directed to assessing the importance in a number of micro-organisms of the tricarboxylic acid cycle as an operative physiological mechanism. The investigations may be divided roughly into two types: examination of the organisms for the presence of the requisite enzymes necessary to carry out the constituent reactions, and the use of isotopic tracer techniques to estimate the dynamics of the cycle as a whole. Investigations of the former type, while providing valuable information on the enzymic constitution of the cells, can offer no more than presumptive evidence for the working of the cycle as a unified entity.

In the latter group of investigations, organisms have been supplied with various compounds, often glucose, acetate, or carbon dioxide, labelled with radioactive carbon in one or more of their atoms. Suspected intermediates were isolated from the cells after a period of utilization of the labelled substrate and degraded to find whether the distribution of labelled carbon in the molecules corresponded with the predictions which could be made assuming that the cycle did operate. Thus Saz \& Krampitz (1954), and Swim \& Krampitz $(1954, a, b)$ showed in large-scale experiments with Micrococcus lysodeikticus and Escherichia coli that the carbon atoms of acetate labelled in either the carboxyl- or the methyl-positions equilibrated with the corresponding atoms

* Present address: Radiation Laboratory, University of California, Berkeley 4, California, U.S.A. 
of citrate, $\alpha$-ketoglutarate, succinate, fumarate, and malate in a manner entirely consistent with the operation of a tricarboxylic acid cycle, but inconsistent with a dicarboxylic acid cycle.

Roberts, Abelson, Cowie, Bolton \& Britten (1955), in a very extensive investigation of Escherichia coli growing on labelled acetate, carbon dioxide, etc., used the distribution of radioactive carbon in the amino acids of the protein as a means of estimating the magnitude of the flow of substances in various branches of the cycle. It was possible for them to determine the extent to which decarboxylations in the cycle were responsible for the production of respiratory carbon dioxide. Their methods have the advantage of requiring the isolation of amino acids rather than of minute quantities of transient intermediates, equilibration between glutamic acid, aspartic acid, and alanine, and their respective keto acids being assumed.

In the present investigation this technique is applied to a study of the flow rates in the Krebs cycle during the growth of the fungus Zygorrhynchus moelleri. It has already been demonstrated that this mould possesses all the enzymes necessary to carry out the sequence of reactions concerned in the tricarboxylic acid cycle (Moses, 1955), and it is now shown that the cycle plays a large part in the mechanism of terminal oxidations.

\section{METHODS}

The organism was grown in media containing either ${ }^{14} \mathrm{CO}_{2}$, or methyl- or carboxyl-labelled acetate as sources of ${ }^{14} \mathrm{C}$. Several amino acids were subsequently isolated and their specific radioactivities determined. In addition, the intramolecular distributions of ${ }^{14} \mathrm{C}$ in the glutamic and aspartic acid specimens isolated were also measured. Determinations were made of the quantities of certain amino acids synthesized during the growth period, as well as of the increases in dry weight and the rates of respiratory gas exchange. The free amino acids present in the cells were investigated. The methods used are described in detail below.

Growth of the cells. Zygorrhynchus moelleri was grown in a glucose $+\mathrm{NH}_{4} \mathrm{Cl}+$ salts medium (250 ml.) as in previous work (Moses, 1954). After growth for $13 \mathrm{hr}$. at $25^{\circ}$, the mycelium then being in its most rapid growth phase, the cells were centrifuged, washed, with a modified growth medium consisting of: $\mathrm{NH}_{4} \mathrm{H}_{2} \mathrm{PO}_{4}, 3.44 \mathrm{~g}$; $\mathrm{KH}_{2} \mathrm{PO}_{4}, 2 \cdot 18$ g.; $\mathrm{MgSO}_{4} .7 \mathrm{H}_{2} \mathrm{O}, 0.04$ g.; $\mathrm{NaCl}$, 0.04 g.; glucose, 4.0 g.; $\mathrm{Na}$ acetate. $3 \mathrm{H}_{2} \mathrm{O}, 0 \cdot 40 \mathrm{~g}$.; dissolved in $400 \mathrm{ml}$. of tap water, and resuspended in $400 \mathrm{ml}$. of the same solution. The solution was adjusted to $\mathrm{pH} \mathrm{5.5}$ with $\mathrm{NaOH}$. This medium was modified from that used in earlier work as follows: $(a)$ acetate was included as a carbon source; (b) $\mathrm{NH}_{4} \mathrm{H}_{2} \mathrm{PO}_{4}$ replaced $\mathrm{NH}_{4} \mathrm{Cl}$ as the nitrogen source in order to stabilize the $\mathrm{pH}$ further as the $\mathrm{NH}_{3}$ was utilized during growth; $(c)$ yeast and liver extracts were omitted in order to be able to define the carbon sources accurately.

The cell suspension was dispensed into the following flasks:

(1) $2 \mathrm{ml}$. were added to each of four Warburg manometer flasks. The $\mathbf{O}_{\mathbf{2}}$ taken up and the $\mathrm{CO}_{2}$ evolved was measured by the direct method of Warburg (Umbreit, Burris \& Stauffer, 1949). 
(2) Three 1 1. Erlenmeyer flasks each received $100 \mathrm{ml}$. of cell suspension. In one flask (A) was suspended a small test-tube containing $200 \mu \mathrm{c}$. of $\mathrm{Ba}^{14} \mathrm{CO}_{3}$ (23 mg.); this was so arranged that ${ }^{14} \mathrm{CO}_{2}$ could be released in the flask by the subsequent addition of acid. A second flask (B) received $100 \mu \mathrm{c}$. of methyllabelled $\mathrm{Na}$ acetate (1.6 mg.) and a third flask (C) $100 \mu \mathrm{c}$. of carboxyl-labelled $\mathrm{Na}$ acetate $(1.9 \mathrm{mg}$.). After mixing, small amounts of suspension were removed from the flasks containing labelled acetate, centrifuged, and the supernatants reserved for subsequent assay of the initial radioactivities in these media.

(3) Two $250 \mathrm{ml}$. Erlenmeyer flasks (D and E) each received $25 \mathrm{ml}$. of cell suspension.

All the Warburg and Erlenmeyer flasks were flushed with pure $\mathrm{O}_{2}$ for $10 \mathrm{~min}$. and then sealed. A preliminary experiment had shown that the $\mathrm{O}_{2}$ in $900 \mathrm{ml}$. of air was insufficient to support the fully aerobic growth of $100 \mathrm{ml}$. of cell suspension for more than about $30 \mathrm{~min}$. at the cell concentration used. Thereafter the R.Q. rose rapidly from about $1 \cdot 1$ to 3, or even higher. With an atmosphere of $\mathrm{O}_{2}$ the R.Q. remained low and constant.

At the start of the experiment ${ }^{14} \mathrm{CO}_{2}$ was released in the flask containing $\mathrm{Ba}^{14} \mathrm{CO}_{3}$ by the addition of acid to the $\mathrm{Ba}^{14} \mathrm{CO}_{3}$. Warburg manometer readings were begun, and samples of the cell suspension were removed from one of the $250 \mathrm{ml}$. Erlenmeyer flasks (D) for dry-weight determinations. Samples were also taken from this flask for determinations, after hydrolysis, of the total amino acid content of the suspensions; these samples were immediately mixed with ethanol.

The various flasks were shaken for $4 \frac{1}{2} \mathrm{hr}$. at $25^{\circ}$. At the end of this period, further samples of the suspension were removed from the two flasks containing labelled acetate, centrifuged, and the supernatants retained for assay of the residual radioactivities in the media. The bulk of the cell suspensions from the three 1 1. Erlenmeyer flasks was separately centrifuged, and each batch of cells was resuspended in $5 \%(\mathrm{w} / \mathrm{v})$ trichloroacetic acid to kill the cells. Replicate samples of the cell suspension were removed from the other $250 \mathrm{ml}$. Erlenmeyer flask (E) for dry-weight measurements, and further samples were mixed with ethanol for the subsequent determination of the total amino acid content after hydrolysis of the proteins. A known weight of cells was also centrifuged and extracted with $70 \%(\mathrm{v} / \mathrm{v})$ ethanol in water for determination of the free (non-protein) amino acids in the cells.

Dry-weight determinations. Samples of the cell suspension were filtered through weighed sintered glass crucibles and dried to constant weight at $105^{\circ}$.

\section{Treatment of the radioactive cell material}

In order to obtain a fraction containing all the insoluble cell nitrogen, each suspension of cells in trichloroacetic acid was treated as follows: after heating at $80^{\circ}$ for $15 \mathrm{~min}$., the suspension was centrifuged. The residue was washed with water, extracted with ethanol for $15 \mathrm{~min}$. at $70^{\circ}$, washed with a mixture of equal parts of ethanol and ether, and finally washed with ether alone. The residue was dried to constant weight for some days in air at $37^{\circ}$; the yield of extracted cells was about $300 \mathrm{mg}$. in each batch. 
(a) Isolation of glutamic and aspartic acids. Each sample of extracted cells was hydrolysed in a sealed vessel at $105^{\circ}$ for $18 \mathrm{hr}$. with a mixture of equal parts of $10 \mathrm{~N}-\mathrm{HCl}$ and glacial acetic acid. After evaporation to dryness, the residue was dissolved in water and a portion retained for chromatography and radioautography of the amino acids. The remainder was passed through a column of Deacidite $\mathrm{E}$ (prepared in the manner described by Partridge \& Brimley (1949) for Deacidite B). Glutamic and aspartic acids were adsorbed on to the resin; they were eluted with $\mathrm{N}-\mathrm{HCl}$ and separated from each other by paper chromatography using a solvent consisting of the organic layer of a mixture of $n$-butanol:acetic acid: water (4:1:5; Partridge, 1948). The amino acids were located by radioautography and eluted from the paper with water.

(b) Isolation of lysine and arginine. Part of the effluent from the Deacidite was chromatographed on paper for 7 days using $n$-butanol:acetic acid:water $(4: 1: 5)$ as the solvent. Lysine and arginine were located by radioautography and eluted.

(c) Isolation of isoleucine, proline and threonine. Isoleucine, proline, threonine and a mixture of valine and methionine were isolated from another portion of the Deacidite effluent by paper chromatography with a solvent consisting of $n$-butanol:ethyl-methyl-ketone:8.5 $\mathrm{N}$-aqueous $\mathrm{NH}_{3}$ (5:3:2; Wolfe, 1957). The amino acids were located as above and eluted.

(d) Isolation of methionine. The mixture of valine and methionine recovered from the previous chromatogram was oxidized with $\mathrm{H}_{2} \mathrm{O}_{2}$ and the oxidized methionine separated from valine by paper chromatography with $n$-butanol: acetic acid: water $(4: 1: 5)$ as the solvent.

All samples of the amino acids isolated were subjected to paper chromatography in two solvents (the $n$-butanol : acetic acid: water, and $n$-butanol : ethylmethyl-ketone: $8 \cdot 5 \mathrm{~N}$-aqueous $\mathrm{NH}_{3}$ solvents used above) to check their purity and identity. To determine the specific activities of the various amino acids, measured samples were taken for radioactivity assays, and for amino acid determinations (Yemm \& Cocking, 1955) after first drying in vacuo with $0 \cdot 1 \mathrm{~N}-\mathrm{NaOH}$ (Fowden, 1951). Proline was estimated by the method of Chinard (1952).

(e) Chromatography of the complete hydrolysate. Samples of the hydrolysed protein were run on two-dimensional chromatograms with $n$-butanol: ethylmethyl-ketone: $8 \cdot 5 \mathrm{~N}$-aqueous $\mathrm{NH}_{3}$ as the first solvent, and $n$-butanol:acetic acid: water as the second. The chromatograms were exposed to $\mathrm{X}$-ray film and subsequently sprayed with an $0.05 \%(\mathrm{w} / \mathrm{v})$ solution of ninhydrin in ethanol.

All these procedures were carried out for the contents of each of the flasks A, B and C.

Determination of the total (free and combined) amino acids. The samples of the whole cell suspensions mixed with ethanol taken at the beginning and end of the experiment (from flasks D and $\mathbf{E}$ respectively) were evaporated to dryness. The proteins were hydrolysed as described above and the amino acids were adsorbed on to a column of Zeocarb 215 (Partridge \& Brimley, 1952). After elution with $2 \mathrm{~N}-\mathrm{NH}_{3}$ the amino acids were chromatographed and determined as described by Wolfe (1957). 
Determination of the free intracellular amino acids. The sample taken for this purpose from flask $\mathrm{E}$ at the end of the experiment was extracted three times with $70 \%(\mathrm{v} / \mathrm{v})$ ethanol in water for $15 \mathrm{~min}$. at $70^{\circ}$. After centrifugation the pooled extracts were evaporated to dryness and the amino acids redissolved in water, adsorbed on to Zeocarb 215, eluted with $\mathrm{NH}_{3}$, and chromatographed as described above. The dried chromatograms were sprayed with ninhydrin and the amounts of the various amino acids present were roughly determined by visual comparison with standard quantities.

Degradation of glutamic and aspartic acids. Samples of each acid were decarboxylated with lyophilized Clostridium welchii (Meister, Sober \& Tice, 1951) to obtain the $\alpha$-carboxyl carbons as $\mathrm{CO}_{2}$; in addition the aspartic acid samples were decarboxylated with ninhydrin (van Slyke, MacFadyen \& Hamilton, 1941) to obtain both carboxyl carbons as $\mathrm{CO}_{2}$. The various products obtained were assayed for radioactivity. The activities of the $\beta$-carboxyl carbons of the aspartic acids were obtained by difference.

Radioactivity determinations. Radioactivity was measured by the "infinitely thin' sample method of Calvin, Heidelberger, Reid, Tolbert \& Yankwich (1949, p. 107). The solution to be counted $(0.05 \mathrm{ml}$.) was pipetted on to a recessed aluminium planchette, $2 \cdot 1 \mathrm{~cm}$. in diameter. The drop was covered with a circle of lens tissue paper, the sample dried under an infrared lamp at about $70^{\circ}$ for $4 \mathrm{~min}$., and counted in a windowless gas flow (methane) proportional counter connected to a scaler.

Samples containing ${ }^{14} \mathrm{CO}_{2}$ absorbed in $\mathrm{N}-\mathrm{NaOH}$ were not converted to the $\mathrm{Ba}$ salt but were applied directly to the planchettes. There was no detectable loss of ${ }^{14} \mathrm{CO}_{2}$ by this method (see also Calvin et al. 1949, p. 122).

Nelson \& Krotkov (1955) determined the activities of samples of labelled glucose, asparagine and glutamine before and after conversion to $\mathrm{BaCO}_{3}$ and found no great difference in specific activities by the two methods.

In order to determine specifically the activity due to acetic acid, acetate samples were counted after drying in the presence of a drop of $2 \mathrm{~N}-\mathrm{HCl}$ (which released the acetic acid) or $2 \mathrm{~N}-\mathrm{NaOH}$ (which retained it).

As the samples possessed appreciable mass, correction was made for the self-absorption of the radiation by the $\mathrm{NaOH}$, lens tissue and sample itself.

Chemicals. All isotopic compounds were obtained from The Radiochemical Centre, Amersham, Buckinghamshire.

\section{RESULTS}

\section{Growth and respiration}

The details of the increases in gas exchange rates and dry weights, and the utilization of radioactive substrates in the medium during the experimental growth period are given in Table 1 . These values refer to the total contents of each of the 1 l. flasks $A, B$ and $C$ used for the growth of the cells on radioactive substrates. There was good agreement between the percentage increases of the rates of gas exchange and of the dry weights.

The rates of oxygen absorption and carbon dioxide evolution at intervals during the course of the experiment, together with the R.Q., are shown in 
Fig. 1. The increases of the rates of gas exchange were linear for both gases, resulting in very little change of $R . Q$. over the whole experiment.

During the experimental period methyl- and carboxyl-labelled acetate was almost completely metabolized; there was some small excretion of nonvolatile labelled substances into the medium (Table 1). Of the total radioactivities in flasks $\mathrm{B}$ and $\mathrm{C}$ at the start of the experiment, only 1.8 and $2.6 \%$, respectively, were not volatile when dried in the presence of acid, i.e. were not acetate. At the end of the experiment these values had risen to $96 \cdot 1$ and $\mathbf{9 5 . 7} \%$ of the activities remaining at this time, though the total activities in the media at the end of the experiment were very much reduced. The activity of the labelled carbon dioxide in flask $\mathbf{A}$ was not measured.

Table 1. Rates of gas exchange, dry weights, and radioactivity in the medium of cell suspensions growing in the presence of labelled carbon dioxide and acetate

Three 1 l. Erlenmeyer flasks each contained $100 \mathrm{ml}$. of a suspension of growing cells, the gas phase being pure $\mathrm{O}_{2}$. One flask was supplied with ${ }^{14} \mathrm{CO}_{2}$, a second with ${ }^{14} \mathrm{CH}_{3} . \mathrm{COOH}$, and a third with $\mathrm{CH}_{3} \cdot{ }^{14} \mathrm{COOH}$, in addition to unlabelled substrates which were identical in each case. The values refer to the totals in each of the three flasks. The cells were grown for $4 \frac{1}{2}$ hr. at $25^{\circ}$.

\begin{tabular}{|c|c|c|c|}
\hline & $\begin{array}{c}\text { Start of } \\
\text { growth period }\end{array}$ & $\begin{array}{c}\text { End of } \\
\text { growth period }\end{array}$ & $\begin{array}{c}\text { Final value } \\
\text { as \% of } \\
\text { initial value }\end{array}$ \\
\hline Rate of $\mathrm{O}_{2}$ uptake (ml./hr.) & $16 \cdot 60$ & $40 \cdot 40$ & $243 \cdot 4$ \\
\hline Rate of $\mathrm{CO}_{2}$ evolution (ml./hr.) & $17 \cdot 36$ & $45 \cdot 98$ & $264 \cdot 9$ \\
\hline$Q_{\mathrm{O}_{3}}(\mu \mathrm{l} . / \mathrm{hr} . / \mathrm{mg}$. dry wt. $)$ & $93 \cdot 3$ & $91 \cdot 6$ & - \\
\hline$Q_{\mathrm{CO}_{2}}(\mu \mathrm{l} . / \mathrm{hr} . / \mathrm{mg}$. dry wt. $)$ & $97 \cdot 5$ & $104 \cdot 3$ & - \\
\hline R.Q. & $1 \cdot 046$ & $1 \cdot 138$ & - \\
\hline Dry weight (mg./flask) & $178 \cdot 0$ & $441 \cdot 0$ & $247 \cdot 8$ \\
\hline \multicolumn{4}{|c|}{ Radioactivity in the medium (counts/min.) } \\
\hline \multicolumn{4}{|c|}{ (a) Suspension supplied with ${ }^{14} \mathrm{CH}_{3} . \mathrm{COOH}$ : } \\
\hline Medium $+\mathrm{NaOH}$ & $60,357,000$ & $3,787,000$ & - \\
\hline Medium $+\mathrm{HCl}$ & $1,089,000$ & $3,640,000$ & - \\
\hline Thus activity due to acetate & $59,268,000$ & 147,000 & $0 \cdot 2$ \\
\hline \multicolumn{4}{|c|}{ (b) Suspension supplied with $\mathrm{CH}_{3} \cdot{ }^{14} \mathrm{COOH}$ : } \\
\hline Medium + NaOH & $80,671,000$ & $3,864,000$ & - \\
\hline Medium $+\mathbf{H C l}$ & $2,111,000$ & $3,699,000$ & - \\
\hline Thus activity due to acetate & $78,560,000$ & 165,000 & $0 \cdot 2$ \\
\hline
\end{tabular}

\section{Total synthesis of amino acids}

Table 2 shows the total quantities of amino acids in the cell suspensions after hydrolysis. The differences between the values for the beginning and end of the experiment show the net quantities of amino acids synthesized in each of the three growth flasks containing labelled substrates. It will be noted that there was not the same percentage increase in each of the amino acids during the period of the experiment. This applied particularly to lysine, i.e. the cells contained relatively more lysine at the beginning of the experiment than at the end. This may be a reflexion of the fact that a fungal hypha grows only at its tips, so that a difference in amino acid composition is understandable between old growth and new growth when cells are grown in different conditions. In 
the case in question, the germination of the spores and the initial growth of the mycelium took place in the medium used in earlier work (Moses, 1954), and in an atmosphere of air; subsequent growth was in a modified medium in an atmosphere of oxygen. On the whole, however, there was good agreement

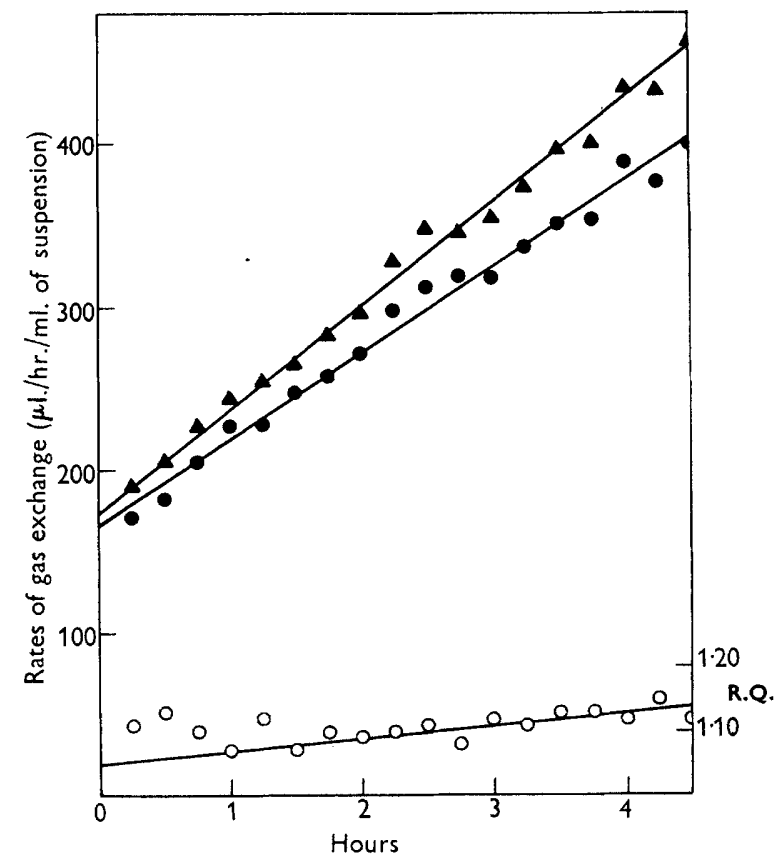

Fig. 1. R.Q. values and rates of gas exchange of growing cells. Each flask contained $100 \mathrm{ml}$. of cell suspension containing initially $178 \mathrm{mg}$. dry wt. of cells. The cells were allowed to grow for $4.5 \mathrm{hr}$. at $25^{\circ}$ in an atmosphere of pure $\mathrm{O}_{2}$. The gas exchange is expressed as $\mu \mathrm{l} . / \mathrm{hr} . / \mathrm{ml}$. of suspension. $\Delta-\Delta$, carbon dioxide evolution; -0 , oxygen uptake; O-O, R.Q.

\section{Table 2. Synthesis of amino acids during growth of the cell suspensions}

Three flasks each contained $100 \mathrm{ml}$. of a suspension of growing cells, the three suspensions differing only in the labelling with ${ }^{14} \mathrm{C}$ of some of the substrates. Samples of the suspensions were taken before and after a $4 \frac{1}{2} \mathrm{hr}$. growth period for determination, after hydrolysis of the cells, of the content of several amino acids in the whole suspensions. The amounts of these amino acids synthesized during the growth period were determined by difference. The values given refer to the total amino acid content of the cell suspensions in each flask.

\begin{tabular}{|c|c|c|c|c|}
\hline Amino acid & $\begin{array}{l}\text { Initial quantity } \\
\text { before growth } \\
(\mu \text { mole })\end{array}$ & $\begin{array}{l}\text { Final quantity } \\
\text { after growth } \\
(\mu \text { mole })\end{array}$ & $\begin{array}{c}\text { Quantity } \\
\text { synthesized } \\
(\mu \text { mole })\end{array}$ & $\begin{array}{l}\text { Percent increase } \\
\text { during growth }\end{array}$ \\
\hline Arginine & 13 & 37 & 24 & 291 \\
\hline Aspartic acid & 67 & 169 & 102 & 252 \\
\hline Glutamic acid & 77 & 216 & 139 & 279 \\
\hline Isoleucine & $\mathbf{3 4}$ & 89 & 55 & 265 \\
\hline Lysine & 135 & 153 & 18 & 113 \\
\hline Methionine & 8 & 23 & 15 & 276 \\
\hline Proline & 42 & 103 & 61 & 248 \\
\hline Threonine & 60 & 151 & 91 & 252 \\
\hline
\end{tabular}


between the percentage increases of most of the amino acids measured, both among themselves, and when compared with the percentage increase in dry weight of the cells.

\title{
Free amino acids present in the cells
}

Twenty ninhydrin-reacting substances were present in hot $70 \%$ ethanolextracts of the cells. Seventeen were identified as amino acids or amides; the other three were present in trace amounts only. Asparagine was absent. Many of the amino acids, and particularly alanine and arginine, were present in fairly large quantities; others were found in lower concentrations (Table 3). Since the nitrogen content of the cells was about $8 \%$ of the dry weight (Moses, 1954), the free amino acids constituted about $3 \%$ of the total cell nitrogen.

\section{Table 3. Free amino acids present in a hot $70 \%(\mathrm{v} / \mathrm{v})$ ethanol extract of growing cells}

\begin{abstract}
Samples of a growing cell suspension were centrifuged and the cells (7.5 mg. dry wt.) extracted with hot $70 \%(\mathrm{v} / \mathrm{v})$ ethanol. The free amino acids present were chromatographed and estimated visually by comparison with standard spots after spraying the chromatograms with ninhydrin: there may be an error of $\pm 100 \%$. The values given are in $\mu \mathrm{g}$. of $\alpha$-amino nitrogen.
\end{abstract}

$\quad$ Amino acid
Alanine
$\gamma$-Aminobutyric acid
Arginine
Aspartic acid
Cystine or cysteine
Glutamic acid
Glutamine
Glycine
Isoleucine
Leucine

Quantity present ( $\mu$ g. of $\alpha$-amino $N)$

5
1
$1 \cdot 5$
$0 \cdot 5$
trace
$0 \cdot 5$
$0 \cdot 5$
1
trace
1

\section{Amino acid}

Lysine
Methionine + valine
Phenylalanine
Proline
Serine
Threonine
Tyrosine
Unknown 1
Unknown 2
Unknown 3

Quantity present ( $\mu$ g. of $\alpha$-amino $\mathrm{N}$ )
0.5
1
0.5
0.5
1
trace
1
trace
trace
trace

Incorporation of labelled carbon into the amino acids of protein

Isotopic carbon was incorporated into some, though not all, of the amino acids of the cellular protein from cells grown on the three tracer substances supplied. Cells supplied with labelled carbon dioxide showed strong radioactivity in aspartic and glutamic acids, arginine, proline, methionine, isoleucine, and threonine, with traces in alanine, valine and glycine. When the cells were grown on either methyl- or carboxyl-labelled acetate the distribution of activity among the various amino acids was nearly identical, suggesting that acetate was incorporated largely as an intact molecule. Activity was found in considerable quantities in both cases in aspartic and glutamic acids, arginine, proline, methionine, isoleucine, threonine, leucine, and lysine, and in an unidentified substance which did not react with ninhydrin. Traces were seen in alanine. Cells supplied with methyl-labelled acetate showed some activity in valine; those grown on carboxyl-labelled acetate appeared not to possess activity in valine, though in this case the chromatographic separation between valine and methionine was poorer than in the other instances. Photographs of the amino acid chromatograms after 
being sprayed with ninhydrin, together with the corresponding radioautograms, are shown in $\mathrm{Pl} . \mathbf{1}$.

The specific activities of a number of amino acids from each sample of hydrolysed protein were determined and are shown in Table 4.

\section{Table 4. Specific activities of various amino acids isolated from cells growing on labelled substrates}

Eight amino acids were isolated from cells growing in a salts $+\mathrm{NH}_{4}^{+}+$glucose + acetate medium in the presence of one of three labelled substrates: ${ }^{14} \mathrm{CO}_{2},{ }^{14} \mathrm{CH}_{3} . \mathrm{COOH}, \mathrm{CH}_{3} .{ }^{14} \mathrm{COOH}$. The specific activities of the amino acids were determined and are expressed as counts/min./ $\mu$ mole.

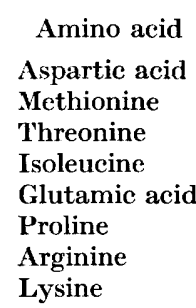

\begin{tabular}{rcc}
\multicolumn{3}{c}{ Tracer supplied } \\
${ }^{14} \mathrm{CO}_{2}$ & ${ }^{14} \mathrm{CH}_{3} \cdot \mathrm{COOH}$ & $\mathrm{CH}_{3} \cdot{ }^{14} \mathrm{COOH}$ \\
24,100 & 12,100 & 9,500 \\
29,300 & 10,800 & 9,100 \\
28,400 & 21,100 & 19,600 \\
28,000 & 16,800 & 16,500 \\
9,300 & 30,100 & 25,800 \\
14,800 & 36,100 & 31,500 \\
33,000 & 24,800 & 22,700 \\
3,700 & 45,600 & 38,300
\end{tabular}

\section{Degradation of aspartic and glutamic acids}

Table 5 shows the intramolecular distribution of activity in the three aspartate and glutamate samples isolated.

Table 5. Distribution of radiocarbon in the aspartic and glutamic samples isolated from cells grown in the presence of labelled substrates

Samples of glutamic and aspartic acid were isolated from cells growing in the presence of ${ }^{14} \mathrm{CO}_{2},{ }^{14} \mathrm{CH}_{3} . \mathrm{COOH}$, or $\mathrm{CH}_{3} \cdot{ }^{14} \mathrm{COOH}$. The amino acids were partially degraded and the specific activities of certain carbon atoms determined. The activities are expressed both as counts/min./ $\mu$ mole, and as a percentage of the activity in the complete molecule.

Labelled substrate

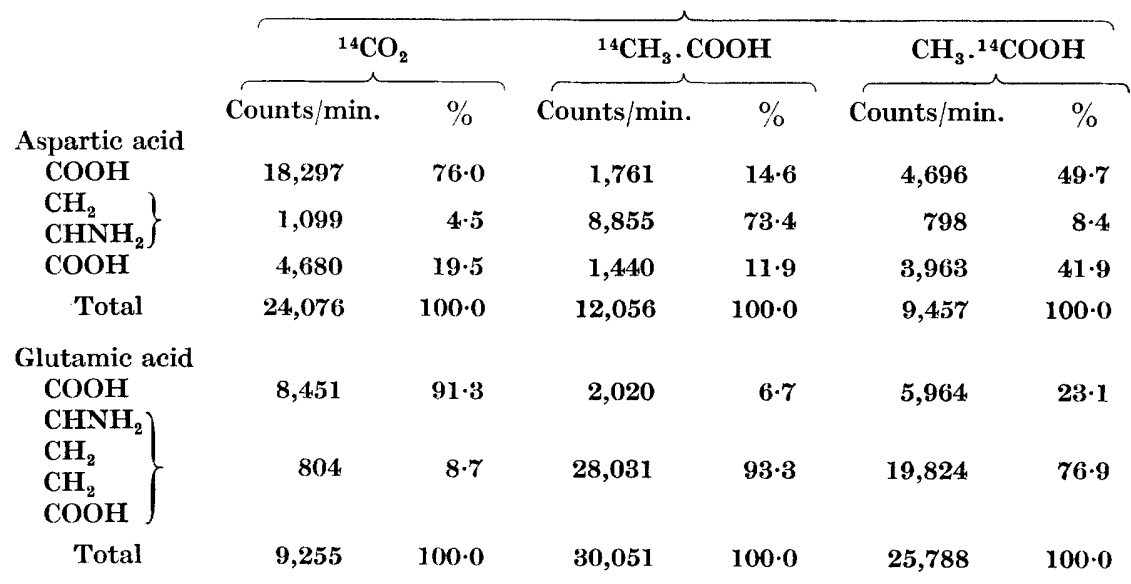




\section{DISCUSSION}

The operation of the citric acid cycle

From a theoretical consideration of the citric acid cycle, certain predictions can be made regarding the intramolecular distribution of radioactivity in some of the cycle products when the labelled substrates provided are marked in certain specified atoms only. It is possible to predict, in particular, the labelling of $\alpha$-ketoglutaric and oxalacetic acids, and assuming that these keto acids are in equilibrium with their corresponding amino acids, the same labelling pattern should hold also for the latter. Close agreement between theoretical prediction and observed fact is good support for the real existence and operation of a proposed system.

When cells are supplied with ${ }^{14} \mathrm{C}$-carbon dioxide, the incorporation of radioactivity should be relatively greater in aspartic acid and its family of amino acids than in the glutamic acid family. All the radiocarbon should be confined to the carboxyl carbons of aspartic acid, and to the $\alpha$-carboxyl carbon of glutamic acid. The activities of the $\alpha$-carboxyl carbon of glutamic acid and the $\beta$-carboxyl carbon of aspartic acid should be similar. Tables 4 and 5 show that with the exception of the last criterion these conditions were broadly fulfilled by cells of Zygorrhynchus moelleri growing in the presence of labelled carbon dioxide. There was evidence of a lack of complete equilibration of radiocarbon, due probably to the presence of the free amino acid pool (see below). This has resulted in a closer agreement between prediction and observation in the distribution of activity within a particular molecular species, than to the relative activities of two different chemical substances. Thus the label was virtually confined to the relevant carboxyl carbons of aspartic and glutamic acids, although the activity of the aspartic $\beta$-carboxyl carbon was greater than that of the glutamic $\alpha$-carboxyl carbon (Tables 4 and 5 ).

With methyl-labelled acetate, the two carboxyl carbons of aspartic acid should be equally active, and should each have the same specific activity as the $\alpha$-carboxyl carbon of glutamic acid. The specific activities of the glutamic family of amino acids should be greater than those of the aspartic family. These considerations also hold for carboxyl-labelled acetate and, in addition, with this tracer substance all the activity in both aspartic and glutamic acids should be confined to the carboxyl carbons. The predictions were broadly confirmed in cells grown on these two species of labelled acetate (Tables 4 and 5 ).

There can therefore be little doubt that not only can the individual reactions of the tricarboxylic acid cycle be carried out by Zygorrhynchus moelleri (Moses, 1955), but the cycle does in fact operate as an organized unit during the growth of the organism. Roberts et al. (1955, chapter 14) have described methods by which the amount of recycling taking place in the cycle can be calculated from the distributions of radioactivity in aspartic and glutamic acids when the cells are grown on various substrates. In a steadystate system in growing cells the Krebs cycle is assumed to have a twofold function: oxidation of acetate and synthesis of amino acids. In its oxidative 
capacity the cycle is purely catalytic, and each molecule of oxalacetic acid entering the cycle by condensation with acetate to form citrate is replaced after one turn of the cycle. For the synthesis of amino acids, however, one molecule of oxalacetate will be lost from the cycle for each molecule of amino acid synthesized, and a fresh molecule must be synthesized from pyruvateand carbon dioxide. If the organisms are supplied with labelled acetate, it can be shown that whereas oxalacetate which has travelled round the cycle is labelled in certain carbon atoms, newly formed oxalacetate will be unlabelled. Thus the extent of labelling within the molecule will be dependent on the percentage of oxalacetate utilized in citrate synthesis which is formed from recycled $\mathrm{C}_{4}$-dicarboxylic acid $(K)$ and on the percentage synthesized de novo from pyruvate and carbon dioxide $(P)$. By measuring the ratios of labelling in the various carbon atoms of glutamic and aspartic acids, and assuming that these reflect the labelling pattern in the corresponding keto acids, it is possible to calculate the ratio $\boldsymbol{P} / \boldsymbol{K}$, either by comparing the specific activities of carbon atoms within each glutamic or aspartic acid molecule, or by comparing the specific activities of the total glutamic and aspartic acid molecules. Table 6 shows some of the values calculated for the $P / K$ ratio in $Z$. moelleri; for the reasons advanced above, the most reliable estimates are those derived from intra- rather than from inter-molecular activities. It is probable that the value for $P / K$ was about $40 / 60$.

\section{Table 6. Degree of recycling in the tricarboxylic acid cycle in growing cells}

Cells were grown in the presence of ${ }^{14} \mathrm{CO}_{2},{ }^{14} \mathrm{CH}_{3} . \mathrm{COOH}$, or $\mathrm{CH}_{3} \cdot{ }^{14} \mathrm{COOH}$. Samples of glutamic and aspartic acid were isolated from each batch of cells, the amino acids were partially degraded, and the specific activities of certain of their carbon atoms were determined. From the ratios of the specific activities of particular carbon atoms the value of $\boldsymbol{P} / \boldsymbol{K}$ was estimated, where $\boldsymbol{P}$ is the \% of oxalacetate synthesized from pyruvate and carbon dioxide at the start of each turn of the citric acid cycle, and $K$ is the $\%$ of recycled $\mathrm{C}_{4}$ acid (for explanation see text).

\section{Method of calculation}

$\boldsymbol{P} / \boldsymbol{K}$

Cells grown in the presence of ${ }^{14} \mathrm{CH}_{3} . \mathrm{COOH}$ :

1. Ratio of specific activities of carbons $(1+4) /(2+3)$ of aspartic acid

2. Ratio of specific activities of carbons $1 /(2+3+4+5)$ of glutamic acid

3. Ratio of specific activities of total glutamic acid/total aspartic acid

Cells grown in the presence of $\mathrm{CH}_{3},{ }^{14} \mathrm{COOH}$ :

4. Ratio of specific activities of carbons $1 /(2+3+4+5)$ of glutamic acid

5. Ratio of specific activities of total glutamic acid/total aspartic acid

* These values are probably less accurate due to incomplete equilibration of the radiocarbon between glutamic and aspartic acids (see text).

\section{Pathways of amino acid biosynthesis}

On the basis of their studies with Escherichia coli, Abelson, Bolton, Britten, Cowie \& Roberts (1953), and McQuillen \& Roberts (1954) found that certain amino acids had very similar specific activities suggesting an intimate metabolic relation between them. A number of amino acid families were defined and it was supposed that the carbon skeletons of the amino acids in a particular 
family were derived undiluted from the same precursor. Thus, in $E$. coli grown on labelled acetate, the amino acids aspartic acid, lysine, methionine, threonine and isoleucine all had similar specific activities and were described as the aspartic family; similarly, the glutamic family included glutamic acid, proline and arginine. The same considerations held for cells grown in the presence of labelled carbon dioxide, except that the specific activity of arginine was much greater than that of proline and of glutamic acid. It was found that the carbon skeleton of the ornithine moiety of arginine originated from glutamate, and the guanidine carbon from carbon dioxide; in this case, therefore, the carbon dioxide contributed additional activity to the arginine molecule.

Although the pattern of specific activities was broadly similar, the results with Zygorrhynchus moelleri were not quite so conclusive. When the specific activity of aspartic acid was high (e.g. when the cells were given labelled carbon dioxide) the activities of threonine, methionine and isoleucine were also high (Table 4), and similarly the values were lower when the aspartate values were lower (cells grown on labelled acetate). Similar relationships existed between glutamic acid, proline and arginine, though here the activities were highest in labelled acetate-grown cells and lowest in those grown with labelled carbon dioxide. The results thus confirm the equivalent findings in Escherichia coli.

Lysine, a member of the aspartic family in Escherichia coli, was very weakly labelled in Zygorrhynchus moelleri grown on ${ }^{14} \mathrm{C}$-carbon dioxide, although aspartic acid was highly active. When methyl- or carboxyl-labelled acetate was used, lysine was far more active than any other amino acid (Table 4). Lysine was evidently not a member of the aspartic family, and from its high specific activity in cells grown on acetate tracer it appeared to arise from the succinate moiety of $\alpha$-ketoglutarate together with acetate (or a related compound) which was in equilibrium with exogenous or cycle acetate (Davis, 1955). The pathway appeared to be similar to that operating in Torulopsis utilis, but different from those of Neurospora crassa, where the acetate portion is not in equilibrium with exogenous acetate (Abelson \& Vogel, 1955), and of Escherichia coli, where lysine is derived from aspartate (Roberts et al. 1955).

In Escherichia coli the agreement between the specific activities of the members of each amino acid family was very good, and in this organism no free amino acid pool was found (Roberts et al. 1955, p. 16). In Zygorrhynchus moelleri, however, the correlation was less precise and a considerable amino acid pool was found to be present (Table 3): it seems probable that the presence of this pool prevented complete equilibration of radioactivity among the various amino acids of each family.

\section{Quantitative significance of the tricarboxylic acid cycles}

From a knowledge of the various amino acids synthesized in the course of the experiment (Table 2), it can be calculated that the products of the citric acid cycle consisted of $263 \mu$ mole of aspartic acid (for the production of aspartic acid, methionine, threonine and isoleucine), 224 $\mu$ mole of glutamic acid (for glutamic acid, proline and arginine synthesis), and $18 \mu$ mole of 
lysine. There may also have been other unknown products. These values, together with a $P / K$ ratio of $40 / 60$, enable a flow diagram to be constructed for the various branches of the tricarboxylic acid cycle (Fig. 2). From these figures, $505 \mu$ mole of oxalacetate must enter the cycle to maintain the steady state conditions and replace the $505 \mu$ mole of amino acids removed from the cycle. As the $P \mid K$ ratio is $40 / 60$ (Table 6 ), the amount of recycled oxalacetate is $783 \mu$ mole. The proportions of aspartic acid arising from oxalacetate by an

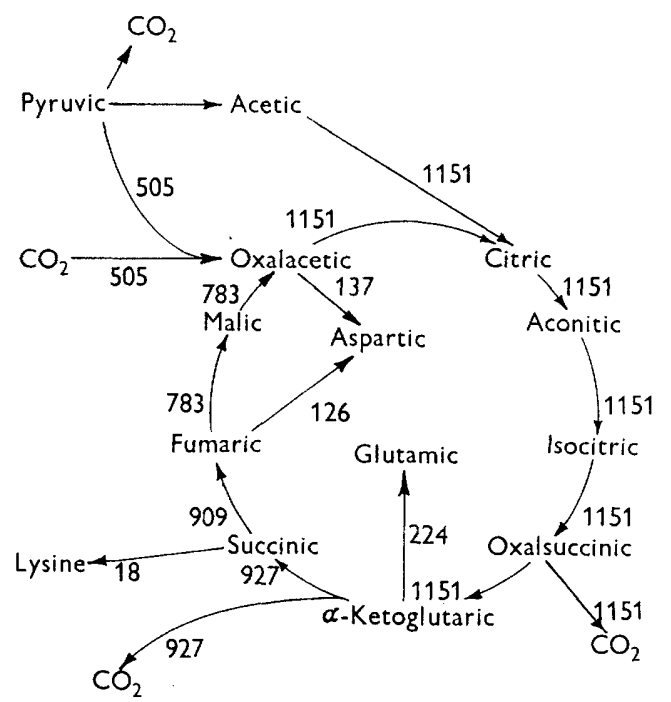

Fig. 2. Flow rates in the tricarboxylic acid cycle of growing cells. The values given are the total flow rates (as $\mu$ mole $/ 4.5 \mathrm{hr}$.) over a $4.5 \mathrm{hr}$. period during which the dry wt. of the cells increased from 178 to $441 \mathrm{mg}$.

asymmetrical (direct) pathway and by a symmetrical pathway (probably via malate and fumarate) can be calculated from the distribution of radiocarbon between the two carboxyl carbons of aspartic acid from cells grown on labelled carbon dioxide (Roberts, Cowie, Britten, Bolton \& Abelson, 1953). Thus $126 \mu$ mole of aspartate arise from fumarate and $137 \mu$ mole from oxalacetate, so that $505+783-137=1151 \mu$ mole of oxalacetate are available for citrate formation. For synthetic purposes 224 $\mu$ mole of glutamic acid are removed, followed by $18 \mu$ mole of lysine and $126 \mu$ mole of aspartic acid, leaving $783 \mu$ mole of recycled oxalacetic acid; the quantity of carbon dioxide produced by cycle decarboxylations can also be deduced, as well as the amount required for the synthesis of fresh oxalacetate from pyruvate. These represent minimum flow rates, as other compounds not investigated in the present work may also arise from the cycle. The flow rates in the different cycle reactions in growing Z Zyorrhynchus moelleri were about $16 \%$ of those in growing Escherichia coli.

During the course of the experiment $6362 \mu$ mole of carbon dioxide were evolved in each of the three growth flasks (calculated from the data of Table 1 and Fig. 1). The citric acid cycle produced $1151 \mu$ mole by the decarboxylation 
of oxalsuccinate, $927 \mu$ mole by $\alpha$-ketoglutarate decarboxylation, and used $505 \mu$ mole for the synthesis of new oxalacetate to replace that diverted into amino acid manufacture; the net production of carbon dioxide from the cycle was thus $1573 \mu$ mole, or $24.7 \%$ of the total.

\section{Comparison with other organisms}

These results confirm that whilst in this organism the cycle largely serves to supply intermediates for organic syntheses (Krebs, Gurin \& Eggleston, 1952), it nevertheless also plays an important part in the terminal oxidation mechanisms and the production of respiratory carbon dioxide. Lewis \& Weinhouse (1951) found with Aspergillus niger that the distribution of isotopic activity in citric acid from cells metabolizing carboxyl-labelled acetate was consistent with the cycle being a major pathway for acetate utilization and citrate formation. Similar conclusions were reached by Yall (1955) from the results of supplying labelled acetate to resting cells of Penicillium chrysogenum. Butterworth, Gilmour \& Wang (1955) found a $\mathrm{C}_{3}-\mathrm{C}_{1}$ condensation together with Krebs cycle activity to be a major pathway of carbon dioxide fixation in Streptomyces griseus, and from the distribution of activity in glutamic acid synthesized by cells of the same organism supplied with carboxyl-labelled acetate (Gilmour, Butterworth, Noble \& Wang, 1955), the $P / K$ ratio can be calculated as 10/90. In Escherichia coli the ratio was about 70/30, and only $\mathbf{2 . 4} \%$ of the respiratory carbon dioxide released originated in the Krebs cycle.

I wish to express my thanks to Dr Miriam Wolfe for allowing me to read the manuscript of her paper. The isotopic chemicals were purchased with a grant from the Royal Society, and the radioactivity assay equipment with a grant from the Central Research Fund of the University of London.

\section{REFERENCES}

Abelson, P. H., Bolton, E., Britten, R., Cowie, D. B. \& Roberts, R. B. (1953). Synthesis of the aspartic and glutamic families of amino acids in Escherichia coli. Proc. nat. Acad. Sci., Wash. 39, 1020.

Abelson, P. H. \& Vogel, H. J. (1955). Amino acid biosynthesis in Torulopsis utilis and Neurospora crassa. J. biol. Chem. $213,355$.

Butterworth, E. M., Gilmour, C. M. \& Wang, C. H. (1955). Studies on the biochemistry of the Streptomyces. II. Fixation of $\mathrm{C}^{14} \mathrm{O}_{2}$ by intact cells of Streptomyces griseus. J. Bact. 69, 725.

Calvin, M., Heidelberger, C., Reid, J. C., Tolbert, B. M. \& Yankwich, P. F. (1949). Isotopic Carbon. New York: John Wiley and Sons Inc.

Chrnard, F. P. (1952). Photometric estimation of proline and ornithine. J. biol. Chem. 199, 91.

Davis, B. D. (1955). Intermediates in amino acid biosynthesis. Advanc. Enzymol. $16,247$.

Fowden, L. (1951). The quantitative recovery and colorimetric estimation of amino acids separated by paper chromatography. Biochem. J. 48, 327.

Gilmour, C. M., Butterworth, E. M., Noble, E. P. \& Wang, C. H. (1955). Studies on the biochemistry of the Streptomyces. I. Terminal oxidative metabolism in Streptomyces griseus. J. Bact. 69, 719. 
Krebs, H. A., Gurin, S. \& Eggleston, L. V. (1952). The pathway of oxidation of acetate in baker's yeast. Biochem. J. 51, 614.

Lewis, K. F. \& Weinhouse, S. (1951). Studies on the mechanism of citric acid production in Aspergillus niger. J. Amer. chem. Soc. 73, 2500.

McQuillen, K. \& RoBerTs, R. B. (1954). The utilization of acetate for synthesis in Escherichia coli. J, biol. Chem. 207, 81.

Meister, A., Sober, H. A. \& Tice, S. V. (1951). Enzymatic decarboxylation of aspartic acid to $\alpha$-alanine. J. biol. Chem. 189, 577.

Moses, V.(1954). The effect of ammonia on the oxidation of glucose by Zygorrhynchus moelleri. Biochem. J. 57, 547.

Moses, V. (1955). Tricarboxylic acid cycle reactions in the fungus Zygorrhynchus moelleri. J. gen. Microbiol. 13, 235.

Nelson, C. D. \& Krotkov, G. (1955). Specific activities of carbon counted in a methane flow proportional counter either as organic carbon or as barium carbonate. Arch. Biochem. Biophys. 59, 294.

Partridge, S. M. (1948). Filter paper partition chromatography of sugars. I. General description and application to the qualitative analysis of sugars in apple juice, egg white, and foetal blood of sheep. Biochem. J. 42, 238.

Partridge, S. M. \& Brimley, R. C. (1949). Displacement chromatography on synthetic ion-exchange resins. 2. The separation of organic acids and acidic amino acids by the use of anion-exchange resins. Biochem. $J .44,513$.

Partridge, S. M. \& Brimley, R. C. (1952). Displacement chromatography on synthetic ion-exchange resins. 8. A systematic method for the separation of amino acids. Biochem. J. 51, 628.

Roberts, R. B., Abelson, P. H., Cowie, D. B., Bolton, E. T. \& Britten, R. J. (1955). Studies of Biosynthesis in Escherichia coli. Washington, D.C.: Carnegie Institution of Washington Publication no. 607.

Roberts, R. B., Cowie, D. B., Britten, R., Bolton, E. \& Abelson, P. H. (1953). The role of the tricarboxylic acid cycle in amino acid synthesis in Escherichia coli. Proc. nat. Acad. Sci., Wash. 39, 1013.

SAz, H. J. \& Krampitz, L. O. (1954). The oxidation of acetate by Micrococcus lysodeikticus. J. Bact. 67, 409.

van Slyke, D. D., MacFadyen, D. A. \& Hamilton, P. (1941). Determination of free amino acids by titration of the carbon dioxide formed in the reaction with ninhydrin. J. biol. Chem. 141, 671.

Swim, H. E. \& Krampitz, L. O. (1954a). Acetic acid oxidation by Escherichia coli: evidence for the occurrence of a tricarboxylic acid cycle. J. Bact. 67, 419.

Swim, H. E. \& Krampitz, L. O. (1954b). Acetic acid oxidation by Escherichia coli: quantitative significance of the tricarboxylic acid cycle. J. Bact. 67, 426.

Umbreit, W. W., Burris, R. H. \& Stauffer, J. F. (1949). Manometric Techniques and Related Methods for the Study of Tissue Metabolism, 2nd ed. Minneapolis: Burgess Publishing Co.

Wolfe, M. (1957). The quantitative determination of amino acids by paper chromatography: a solvent to replace phenol. Biochim. biophys. Acta, 23, 186.

YALL, I. (1955). Pathways of acetate oxidation in Penicillium chrysogenum Q-176. Dissert. Abstr. 15, 1703.

Yemm, E. W. \& Cocking, E. C. (1955). The determination of amino acids with ninhydrin. Analyst, 80, 209. 
Journal of General Microbiology, Vol. 16, No. :3

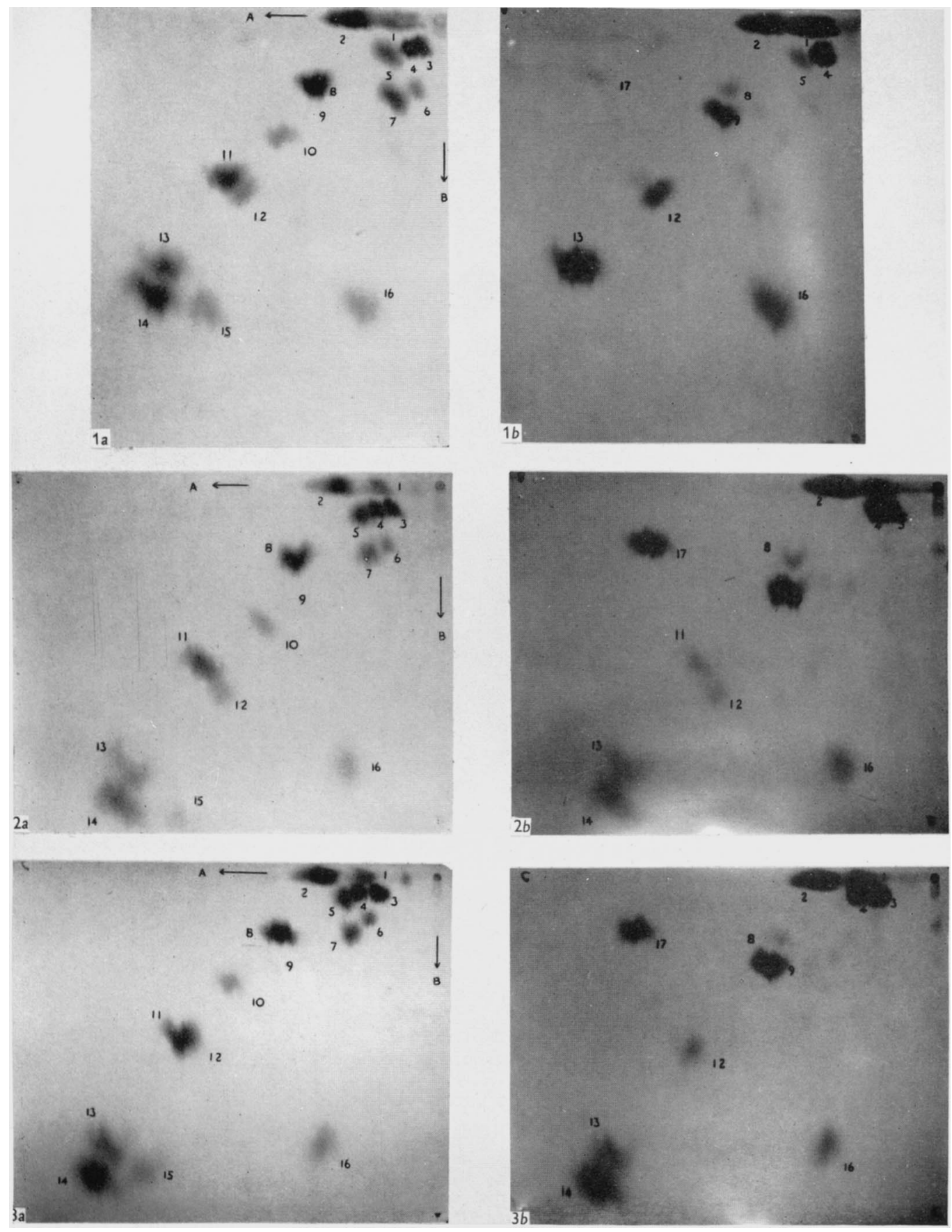

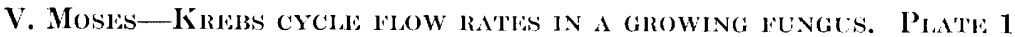

(Facing p. 549) 


\section{EXPLANATION OF PLATE}

Photographs of the chromatograms (after being sprayed with ninhydrin) and the corresponding radioautograms of the protein hydrolysates from cells growing on one of three labelled substrates.

1. Cells grown on labelled carbon dioxide. (a) chromatogram; (b) radioautogram.

2. Cells grown on methyl-labelled acetate. $(a)$ chromatogram; $(b)$ radioautogram.

3. Cells grown on carboxyl-labelled acetate. (a) chromatogram; (b) radioautogram.

Key : 1 , aspartic acid; 2 , glutamic acid; 3 , lysine ; 4 , arginine; 5 , glycine; 6 , histidine ; 7 , serine; 8 , alanine; 9 , proline; 10 , tyrosine ; 11, valine; 12 , methionine ; 13 , isoleucine; 14, leucine; 15, phenylalanine; 16, threonine; 17, unknown (not ninhydrin-reactive). Solvent directions: $A, n$-butanol:acetic acid:water; $B, n$-butanol:ethyl-methylketone: $8 \cdot 5 \mathrm{~N}$-aqueous $\mathrm{NH}_{3}$.

(Received 19 September 1956) 